\title{
Correction to: Precocious maturation in male tiger pufferfish Takifugu rubripes: genetics and endocrinology
}

\author{
Sota Yoshikawa ${ }^{1,2} \cdot$ Hisashi Chuda $^{3} \cdot$ Masaomi Hamasaki $^{1} \cdot$ Kazushi Kadomura $^{1} \cdot$ Toshiyuki Yamada $^{1}$. \\ Kiyoshi Kikuchi ${ }^{2}$ Sho Hosoya ${ }^{2}$ (1)
}

Published online: 1 April 2021

(c) The Author(s) 2021

\section{Correction to: Fisheries Science (2020) 86:339-351 https://doi.org/10.1007/s12562-019-01390-4}

The article "Precocious maturation in male tiger pufferfish Takifugu rubripes: genetics and endocrinology", written by Sota Yoshikawa, Hisashi Chuda, Masaomi Hamasaki, Kazushi Kadomura, Toshiyuki Yamada, Kiyoshi Kikuchi and Sho Hosoya was originally published Online First without Open Access. After publication in volume 86, issue 2, page 339 -351 the author decided to opt for Open Choice and to make the article an Open Access publication. Therefore, the copyright of the article has been changed to (C) The Author(s) 2021 and the article is forthwith distributed under the terms of the Creative Commons Attribution 4.0 International License (https://creativecommons.org/licenses/by/4. 0/), which permits use, sharing, adaptation, distribution and reproduction in any medium or format, as long as you give appropriate credit to the original author(s) and the source,

The original article can be found online at https://doi.org/10.1007/ s12562-019-01390-4.

\section{Sho Hosoya}

ahosoya@mail.ecc.u

Sota Yoshikawa

sota.yoshikawa@pref.nagasaki.lg.jp

Hisashi Chuda

chuda@kindai.ac.jp

Masaomi Hamasaki

m.hamasaki@pref.nagasaki.lg.jp

Kazushi Kadomura

kadomura012220@pref.nagasaki.lg.jp

Toshiyuki Yamada

yamadat@pref.nagasaki.lg.jp provide a link to the Creative Commons licence, and indicate if changes were made. The original article has been corrected.

Open Access This article is licensed under a Creative Commons Attribution 4.0 International License, which permits use, sharing, adaptation, distribution and reproduction in any medium or format, as long as you give appropriate credit to the original author(s) and the source, provide a link to the Creative Commons licence, and indicate if changes were made. The images or other third party material in this article are included in the article's Creative Commons licence, unless indicated otherwise in a credit line to the material. If material is not included in the article's Creative Commons licence and your intended use is not permitted by statutory regulation or exceeds the permitted use, you will need to obtain permission directly from the copyright holder. To view a copy of this licence, visit http://creativecommons.org/licenses/by/4.0/.

Publisher's Note Springer Nature remains neutral with regard to jurisdictional claims in published maps and institutional affiliations.

Kiyoshi Kikuchi

akikuchi@mail.ecc.u-tokyo.ac.jp

1 Nagasaki Prefectural Institute of Fisheries, 1551-4, Taira, Nagasaki, Nagasaki 851-2213, Japan

2 Fisheries Laboratory, Graduate School of Agricultural and Life Sciences, University of Tokyo, 2971-4, Bentenjima,Maisaka, Hamamatsu, Shizuoka 431-0214, Japan

3 Aquaculture Research Institute, Kindai University, 3153,Shirahama, Nishi-muro, Wakayama 649-2211, Japan 